\title{
Tree Species Composition and Diversity in Oban Forest Reserve, Nigeria
}

\author{
Humphrey Igbinosa Aigbe (Corresponding author) \\ Department of Forestry and Wildlife Management, Faculty of Agriculture \\ University of Port Harcourt, Choba, Port Harcourt, Nigeria.
}

Tel: 234-803-401-0803 E-mail: igaigbe@yahoo.com

\begin{abstract}
Godwin Ejakhe Omokhua
Department of Forestry and Wildlife Management, Faculty of Agriculture

University of Port Harcourt, Choba, Port Harcourt, Nigeria
\end{abstract}

Tel: 234-803-337-3792 E-mail: profomokhua@yahoo.com

Received: July 8, 2014 Accepted: July 18, 2014

doi:10.5296/jas.v3i1.6461ＵRL: http://dx.doi.org/10.5296/jas.v3i1.6461

\begin{abstract}
Tree species composition and diversity were assessed in Oban Forest Reserve. Three stage sampling procedure was used to collect data on tree parameters - diameter at breast height (dbh); diameters over bark at the base, middle and top; merchantable height and total height using a minimum dbh limit of $\geq 10 \mathrm{~cm}$ in the tertiary sample plots. A total of 808 trees were measured and 72 species identified in the study area. Stand level parameters were estimated and tree diversity assessed. Results indicate that an average number of stems encountered per hectare were 306. Population densities of individual tree species ranged from 1 to $22 \mathrm{ha}^{-1}$. Population densities of species were poor. The basal area/ha estimated is $34.67 \mathrm{~m}^{2}$ and the species richness index obtained was 10.605 , which indicate high species richness. The value of Shannon's Index $\left(\mathrm{H}^{\mathrm{I}}\right)$ is 3.795 which is quite high. The results show that the forest reserve is a well-stocked tropical rainforest in Nigeria. The relative richness of the forest reserve in terms of individual tree species does not correlate well with the abundance because the abundance of each of the species was quite low and density poor. While there is paucity of most species, Staudtia stipitata was the most abundant (22 tree/ha). The forest has reverted back to the turbulent agrading stage of the forest growth cycle.
\end{abstract}

Keywords: Oban Forest Reserve, Species diversity, Tree density, Floristic composition 


\section{Introduction}

Oban Forest Reserve habours a significant portion of Nigeria's remaining tropical rainforest. The entire landscape is recognized internationally as biodiversity hotspot (USAID, 2006). The tropical rainforest has been identified as the most biologically diverse terrestrial ecosystem on earth (Turner, 2001; Gillespie et al., 2004, Onyekwelu et al., 2008; Schmitt et al., 2009, FAO 2010, and IUCN 2010). In terms of tree composition and species diversity, tropical rain forests are Earth"s most complex ecosystems (Gebreselasse, 2011). Trees are often the most conspicuous plant life form in a typical tropical rainforest. The rainforest act as main repository of the genetic diversity of both flora and fauna.

Nigerian land, which covers a total area of 92.4 million hectares, has 9.7 million hectares, about $10 \%$ of the country, as forest reserves (ITTO, 2011). Out of which, only a small part of this forest is lowland rainforest. Even in the late 1990s it was estimated that only 1.19 million hectares of lowland rainforest remained in the country, and about 288000 hectares of which was in official forest reserves (ITTO, 2011). The degradation, fragmentation and conversion of the forests to other forms of land uses in Nigeria, are currently progressing at alarming rates. Between 1990 and 2000, Nigeria lost about $2.7 \%$ of its natural forests to deforestation which increased to about 18.56\% (about 2.06 million ha) between 2000 and 2010 (FRA, 2010; FAO, 2011). A cumulative 47.5\% of Nigeria's natural forests were lost to deforestation between 1990 and 2010 (FRA, 2010). Recent global forest resources assessment revealed that Nigeria is one of the five countries in the world with the highest annual rate of deforestation for the period 2000 - 2010 (FRA, 2010). These changes have caused the loss of some plant species and a decline in the biodiversity conservation status of the forest and environmental quality. The sustainable management and use of these resources is essential for the nation's economic and environmental security (Akinsanmi, 1999). The need to provide adequate quantitative and qualitative ecological data to guide forest owners and managers in fashioning out realistic and effective management strategies is imperative. This study therefore provides baseline and impact data on species composition and diversity in Oban Forest Reserve, Nigeria.

\section{Methodology}

Oban Forest Reserve lies within longitude $8^{\circ} 20^{\prime} \mathrm{E}$ and $8^{\circ} 55^{\prime} \mathrm{E}$ and latitudes $5^{\circ} 00^{\prime} \mathrm{N}$ and $6^{\circ} 00^{\prime}$ N. Presently, it cover an area of $742.55 \mathrm{~km}^{2}$ (figure 1). 


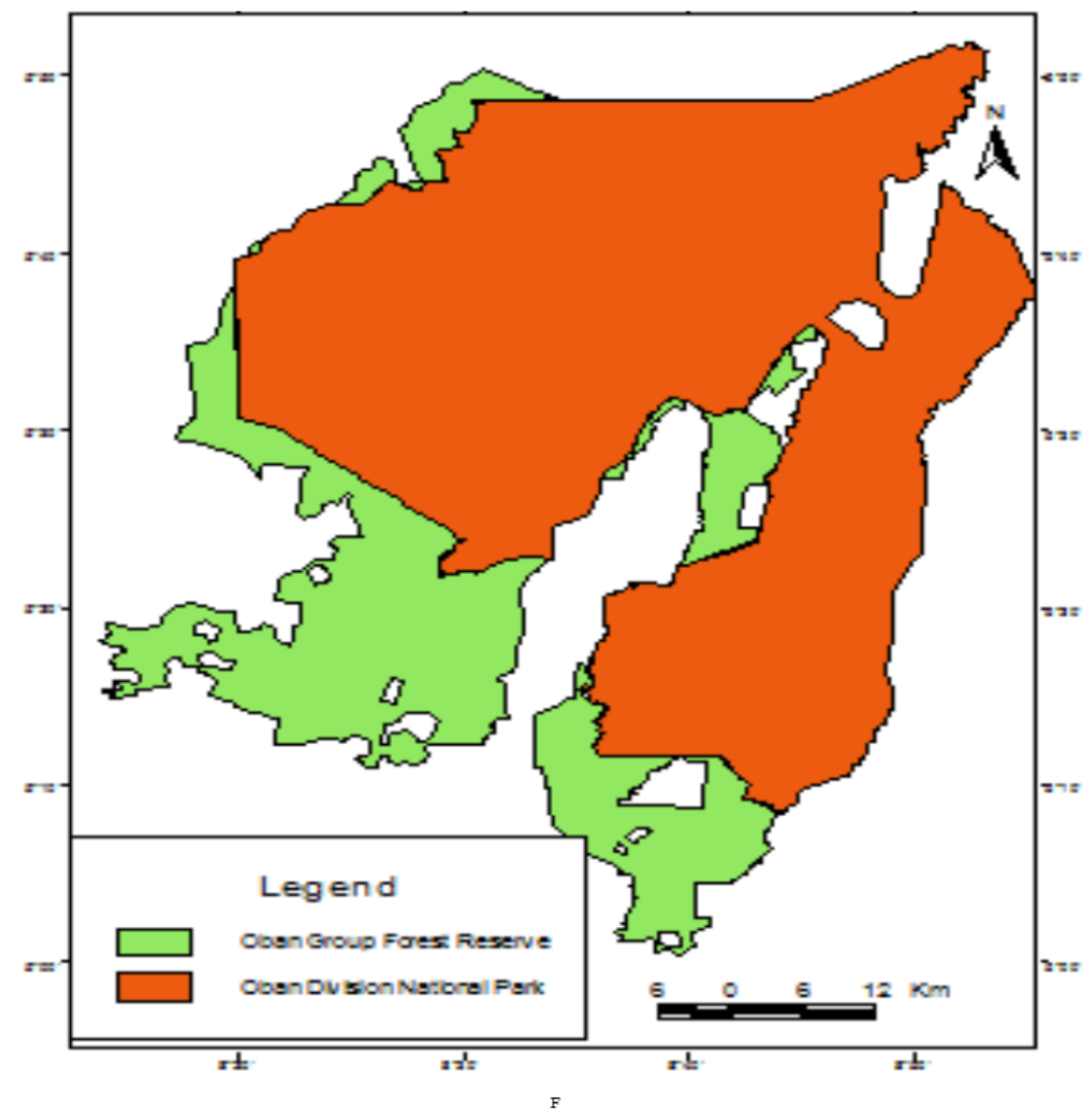

Figure 1. Map of Oban Forest Reserve

The terrain is rugged and elevation rises from the river valleys to over 1,000 $\mathrm{m}$ in mountainous areas (Jimoh et al., 2012). Most of the area is characterized by hilly terrain ranging from 100 to over $1,000 \mathrm{~m}$. The dominant rock types are ancient metamorphic rocks of the Basement Complex which covers $50 \%$ of Nigeria. The metamorphic rocks are mainly gneisses (biotite-hornblende, granite and migmatitic gneiss and to a lesser extent amphibolite (schist) (Holland et al, 1989; Schmitt, 1996). Less sandy soils are found in areas with igneous rocks and deeper soils prevail in the plains of the southern part of the park whilst on steeper slopes they are increasingly stony, shallow and erodible (Holland et al, 1989).

Temperatures are generally high (average around $27^{\circ} \mathrm{C}$ ) and vary little throughout the year with the annual range of the monthly average temperature varying only between $3^{\circ}$ and $3.5^{\circ} \mathrm{C}$. Mean monthly relative humidity varies between $78 \%$ and $91 \%$ with an average of Annual rainfall is generally, between $2,500 \mathrm{~mm}-3,000 \mathrm{~mm}$. At times, it can be up to $4,000 \mathrm{~mm} .85 \%$. (Holland et al, 1989; Schmitt, 1996).

\subsection{Data Collection}

Multistage sampling technique was used to establish primary (1000m x 1000m), secondary $(1000 \mathrm{~m} \times 50 \mathrm{~m})$ and tertiary $(40 \mathrm{~m} \times 50 \mathrm{~m})$ plots. Fourteen tertiary plots were randomly established within the secondary plots and trees randomly selected for measurement within the tertiary plots $(0.20 \mathrm{ha})$. Growth data including: diameter at breast height (dbh, at $1.3 \mathrm{~m})$; 


\section{Macrothink}

Journal of Agricultural Studies

ISSN 2166-0379

2015, Vol. 3, No. 1

diameters over bark at the base, middle and merchantable top; merchantable height and total height were collected on trees with $\mathrm{dbh} \geq 10 \mathrm{~cm}$ in all the 14 tertiary sample plots.

\subsection{Data Analysis}

\section{Basal Area Estimation}

The basal area for each tree in the enumerated plots was computed using:

$$
B A=\pi D^{2} / 4
$$

Where $\mathrm{BA}=$ basal area $\left(\mathrm{m}^{2}\right)$

$$
\begin{aligned}
& \pi=3.142 \text { (a constant) } \\
& \mathrm{D}=\mathrm{dbh}(\mathrm{m})
\end{aligned}
$$

Basal area per plot was obtained by adding the basal area of all individual trees within the plot. Mean plot basal area were computed by summing the total plot basal areas of the sample plots selected from the primary unit and dividing by the number of sample plots selected from that primary unit . Basal area per hectare was then obtained by multiplying the mean plot basal area by the number of sample plots per hectare.

\subsection{Diversity Analysis}

The Shannon-Weiner diversity $\left(\mathrm{H}^{\prime}\right)$, Evenness (E) and Simpson Dominance index were all calculated to determine the tree species diversity.

\subsubsection{Shannon-Wiener Diversity Index $\left(\mathrm{H}^{\mathrm{I}}\right)$}

The Shannon-Wiener diversity index has been the most widely used index in community ecology, equation 3 is used in computing this index.

$$
H^{\prime}=\sum_{\mathrm{i}=1}^{\mathrm{s}} \mathrm{pi} \ln (\mathrm{pi})
$$

Where:

$\mathrm{H}^{\prime}=$ Shannon diversity index

$\boldsymbol{P}_{i}=$ proportion $\mathrm{S}$ (species in the family) made up of the $\mathrm{i}^{\text {th }}$ species

$\ln =$ natural logarithm

The values of Shannon-Wiener diversity index is usually found to fall between 1.5 and 3.5 and only rarely surpasses 4.5 (Magurran, 1988).

\subsubsection{Species Evenness Index (E)}

The ratio of the observed diversity $(\mathrm{H})$ to the maximum diversity $\left(\mathrm{H}_{\max }\right)$ is taken as a measure of evenness (E). 


$$
\text { Evenness }=\frac{H}{H_{\max }}=\frac{H}{\log s}
$$

Where $\mathrm{S}$ is the total number of species. If $H^{I}$ is used, therefore,

$$
\text { Evenness } E^{I}=\frac{H^{I}}{I n S}
$$

$\mathrm{E}$ is constrained between 0 and 1.0 with 1.0 representing a situation in which all species are equally abundant.

\subsubsection{Simpson's dominance Index}

Simpson's dominance index is weighted towards the abundance of the commonest species.

$$
\text { Simpson Index }(\mathrm{C})=\sum P_{i}^{2}
$$

Where $\mathrm{P}_{\mathrm{i}}$ is the proportional abundance of the ith species $\left(\boldsymbol{P}_{\boldsymbol{i}}=\frac{\boldsymbol{n}_{\boldsymbol{i}}}{\boldsymbol{N}}\right)$

Simpson's index varies from 0 to 1 and gives the probability that two individuals drawn at random from a population belong to the same species. If the probability is high, then the diversity of the community sample is low. The higher the dominance index the lower the Shannon diversity.

An unbiased estimator for sampling from an infinite natural population, which is the modified formula is:

$$
D=\sum \frac{n_{i}\left(n_{i}-1\right)}{N(N-1)}
$$

The reciprocal $\left(D^{l}\right)$ of Simpson's index (defined as number of very abundant species) will ensure that the index $D^{l}$ increases with increasing diversity.

2.3.4 Species Richness

$$
\text { Margalef' Index }(\mathrm{d})=\frac{S-1}{\operatorname{In}(N)}
$$

Where $\mathrm{S}$ is the total number of species, ' $\mathrm{N}$ ' is the total number of individuals and ' $I n$ ' is the natural logarithm. 


\section{Results and Discussion}

A total of 808 trees in different girth classes were measured in 14 tertiary sample plots $(40 \mathrm{~m} \mathrm{x}$ $50 \mathrm{~m}$, temporary) from the forest reserve. The results indicate that Oban Forest Reserve has an average density of 306 trees per hectare (Table 1). Findings from research conducted across different eco-regions of the tropics reveal diverse results. In tropical Barro Island, Panama, Hubbell and Foster (1983) and Thorington et al (1983) reported 152/ha and 171/ha respectively; while Ho et al, (1987) found 104/ha in tropical Jengka Reserve, Malaysia. However, Oban Forest Reerve has lower tree density than the 385/ha and 535/ha reported by Sidiyasa, (2001) in Wain River, East Kalimantan, and 1420/ha (Campbell et al, 1986) and 1720/ha (Campbell et al, 1992) both in tropical Amazonia forest.

Although the minimum and maximum dbh range from $10 \mathrm{~cm}$ and $138 \mathrm{~cm}$, tree distribution was positively skewed towards lower dbh classes (figure 2); implying that the forest reserve has reverted to agrading and fairly turbulent stage of the forest growth cycle which is often characterized by high abundance of trees with smaller dbh. Similar results have been reported by scientists in other parts of Nigeria ( $c f$. Adekunle et al., 2004; Adekunle and Olagoke, 2008) and other tropical regions (e. g. Boubli et al., 2004 and Bobo et al., 2006). The reason for relatively fewer number of tree individuals of larger dbh values greater than $50 \mathrm{~cm}(\mathrm{dbh}>50 \mathrm{~cm})$ can be attributed to limited number of species that naturally grow up to this diameters (Hartshorn, 1980) and the numbers of certain big tree species could have been already reduced by selective extraction for some uses in the past (Hadi et al., 2009).

The minimum and maximum merchantable height obtained is $1.74 \mathrm{~m}$ and $40 \mathrm{~m}$ respectively. The minimum and maximum total tree heights indicate $4.5 \mathrm{~m}$ and $44 \mathrm{~m}$ respectively for the forest reserve. The basal area/ha recorded in this study is $34.67 \mathrm{~m}^{2}$. The value obtained in the forest reserve is higher than those reported by Adekunle et al, (2004) and reasonably high when compare to basal area/ha reported by Kumar et al, (2002) for other tropical forest of the world. And also, it is higher than the $15 \mathrm{~m}^{2}$ suggested by Alder and Abayomi, (1994), for a well-stocked tropical rainforest in Nigeria. This is to be expected since the study area is under protection by law, with minimal human use pressure and also the high annual precipitation rate and equable tropical climate of the study area may have contributed to high tree growth rates and high tree basal area. The high basal area value obtained in this study is an indication that Oban Forest Reserve is probably one of the richest of the tropical rainforest left in Nigeria. This may also indicate that, the reserve is probably well regulated.

Table 1. Result of preliminary data analysis.

\section{Oban Forest Reserve}

\begin{tabular}{|l|c|c|c|c|}
\hline $\begin{array}{c}\text { Number of } \\
\text { trees/hectare }\end{array}$ & \multicolumn{4}{|c|}{306} \\
\hline & Min & Max & Mean & Std Error \\
\hline $\mathrm{Dbh}(\mathrm{cm})$ & 10.0 & 138.0 & 33.7 & 0.007 \\
\hline $\mathrm{D}_{\text {st }}(\mathrm{cm})$ & 11.1 & 160.0 & 38.1 & 0.008 \\
\hline $\mathrm{MTH}(\mathrm{m})$ & 1.74 & 40 & 16.94 & 0.265 \\
\hline $\mathrm{THT}(\mathrm{m})$ & 4.5 & 44 & 21.65 & 0.254 \\
\hline $\mathrm{BA} / \mathrm{ha}\left(\mathrm{m}^{2} / \mathrm{ha}\right)$ & 24.84 & 60.44 & 34.67 & 0.0051 \\
\hline
\end{tabular}




\section{Macrothink}

Dbh- diameter at breast height; $\mathrm{D}_{\text {st }}$-stump diameter; MTH- merchantable height; THT- total tree height; BA- basal area

\section{Histogram}

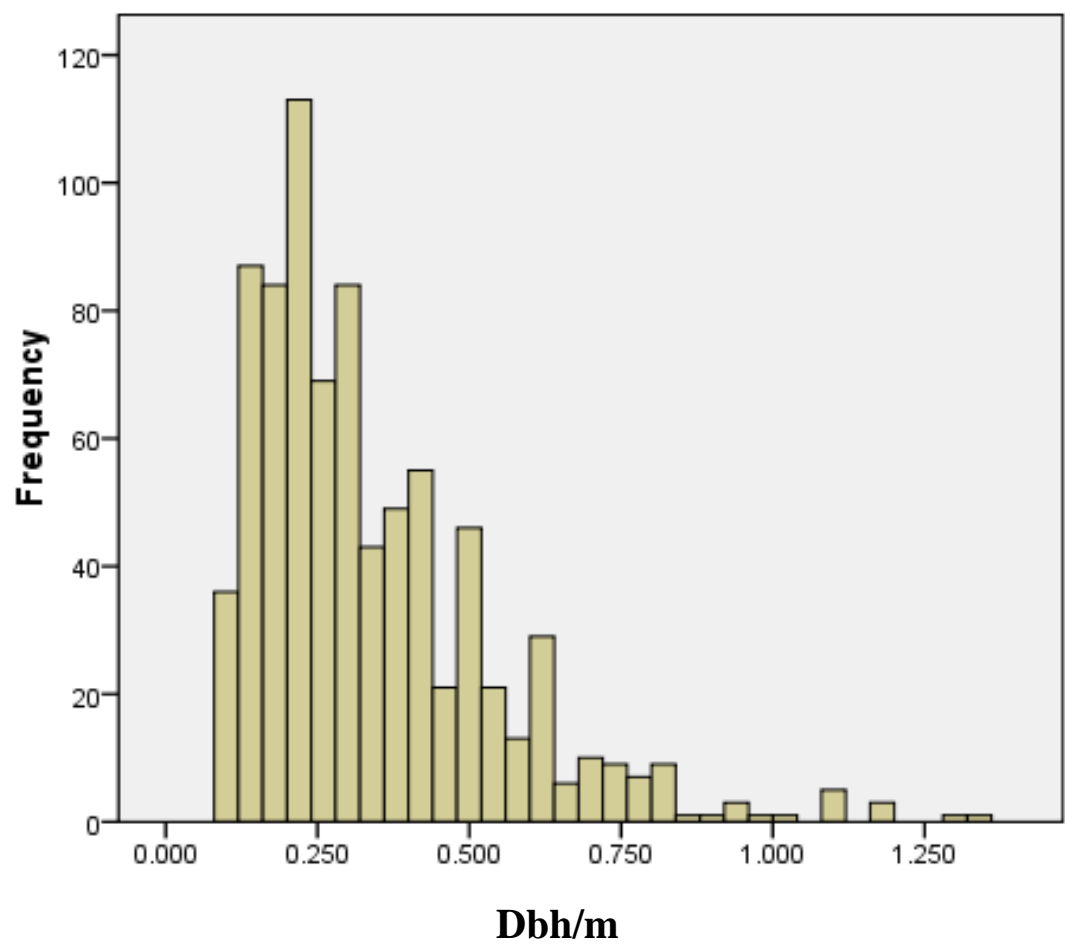

$\begin{aligned} \text { Mean } & =0.34 \\ \text { Std. } \text { Dev. } & =0.198\end{aligned}$

$\mathrm{N}=808$

Figure 2. Dbh Distribution Pattern of Oban Forest Reserve

\subsection{Floristic Composition}

A total of 72 species distributed into 30 families and 65 genera were identified in the study area (Table 2 and 3). The following tree species (Futumia elastica, Uapaca heudelotti, Carapa procera, Pycnathus angolensis, Staudtia stipitata, Sterculia oblonga and Celtis zenkeri) were more prevalent in the study area with an average trees per hectare greater than or equal to nine (trees/ha $\geq 9$ ). Staudtia stipitata and Uapaca heudelotti are the richest individual species with an average of 22 and 19 trees per hectare respectively, which represent $7.6 \%$ and $6.5 \%$ of the total tree stand respectively (Table 2). As shown in table 3, the following families (Apocynaceae, Caesalpinioideae, Combreteceae, Ebenaceae, Euphorbiaceae, Meliaceae, Mimosoideae, Moraceae, Myristicaceae, Papilionoideae, Steculiaceae and Ulmaceae) have average tree species per hectare greater than ten (trees/hectare $>10$ ). Caesalpinioideae is the richest family being represented by 10 species and 10 genera. The second richest family is Mimosoideae with 7 species and 5 genera followed by Meliaceae consisting of 5 species and 5 genera. The following species (Alstonia boonei, Ceiba pentandra, Detarium macrocarpum, Distemonathus benthamianus, Agauria salicifolia, Allanblackia floribunda, Hypodaphnis zenkeri, Petersianthus macrocarpus, Khaya ivorensis, Lovoa trichilioides, Cylicodiscus 
gabunensis, Tetrapleura tetraptera, Treculia obovoidea, Coelocaryon preussii, Pentaclethra mycophylla, Pterocarpus soyauxii, Anopyxis Klaineana, Nauclea diderrichii, and Cola spp.) had one tree species per hectare and are threaten to go into extinction due to anthropogenic factor except urgent steps therefore need to be taken to arrest the dwindling density of timber species.

The poor population density encountered in the study area, may be attributed to unfavorable microclimate within the forests and the paucity of viable seeds of the trees to sustain regeneration. For instance, a tree species that is not shade tolerant would find it difficult to regenerate in a rainforest with closed canopy, which definitely would affect the population density of such a tree species. Christie and Armesto (2003) reported very low population densities of quite a number of economically valuable tree species occasioned by dearth of viable seeds and poor micro-sites for regeneration. Also, abundance or rarity of a timber tree species of economic value in an area of rainforest is a function of the intensity and pattern of its exploitation. Therefore, the fewer population of individual tree species observed in the study areas can be linked to anthropogenic factor. This would also cause gross inadequacy of seeds for regeneration, as a lot of mother trees must have been felled. It is of the fact that, there is a positive relationship between poor population densities of some tree species and the mortality of their old mother trees (Olajide, 2004).

Table 2. Timber Species of Oban Forest Reserve Identified by their Families and Relative Density

\begin{tabular}{|l|l|l|l|}
\hline Family & Species name & No. of stem per Hectare & Relative Density/Hectare \\
\hline Anacardiaceae & Lannea welwitschii & 6 & 0.01854 \\
\hline Anisophylleaceae & Poga oleosa & 7 & 0.02224 \\
\hline Annonaceae & Pachypodathium staudtii & 2 & 0.00494 \\
\hline Annonaceae & Xylopia aethiopica & 2 & 0.00741 \\
\hline Apocynaceae & Alstonia boonei & 1 & 0.00371 \\
\hline Apocynaceae & Futumia elastica & 9 & 0.02842 \\
\hline Apocynaceae & Voacanga africana & 2 & 0.00618 \\
\hline Bombacaceae & Bombax buonopozense & 3 & 0.00865 \\
\hline Bombacaceae & Ceiba pentandra & 1 & 0.00371 \\
\hline Burseraceae & Canarium schweinfurthii & 5 & 0.0173 \\
\hline Caesalpinioideae & Afzelia Africana & 7 & 0.02224 \\
\hline Caesalpinioideae & Berlinia grandiflora & 2 & 0.00618 \\
\hline Caesalpinioideae & Brachystegia eurycoma & 4 & 0.01483 \\
\hline Caesalpinioideae & Daniellia ogea & 8 & 0.02719 \\
\hline Caesalpinioideae & Detarium macrocarpum & 1 & 0.00247 \\
\hline Caesalpinioideae & Distemonathus benthamianus & 1 & 0.00124 \\
\hline Caesalpinioideae & Erythrophleum suaveolens & 3 & 0.00989 \\
\hline Caesalpinioideae & Gossweilerodendron balsamiferum & 7 & 0.02472 \\
\hline Caesalpinioideae & Hylodendron gabunense & 2 & 0.00618 \\
\hline Caesalpinioideae & Oxystigma manni & 2 & 0.00618 \\
\hline
\end{tabular}




\begin{tabular}{|l|l|l|l|}
\hline Combretaceae & Terminalia ivorensis & 8 & 0.02842 \\
\hline Combretaceae & Terminalia superba & 6 & 0.01977 \\
\hline Ebenaceae & Diospyros crassiflora & 15 & 0.05067 \\
\hline Ericaceae & Agauria salicifolia & 1 & 0.00124 \\
\hline Euphorbiaceae & Klainedoxa gabonensis & 3 & 0.01112 \\
\hline Euphorbiaceae & Ricinodendron africanum & 2 & 0.00741 \\
\hline Euphorbiaceae & Uapaca heudelotii & 19 & 0.0655 \\
\hline Flacourtiaceae & Homalium spp. & 7 & 0.02224 \\
\hline Guttiferae & Allanblackia floribunda & 1 & 0.00124 \\
\hline Guttiferae & Mamea Africana & 3 & 0.00865 \\
\hline Irvingiaceae & Irvingia gabonensis & 7 & 0.02472 \\
\hline Lauraceae & Hypodaphnis zenkeri & 1 & 0.00371 \\
\hline Lecythidaceae & Petersianthus macrocarpus & 1 & 0.00124 \\
\hline Loganiaceae & Anthocleista djalonensis & 2 & 0.00494 \\
\hline Meliaceae & Carapa procera & 15 & 0.05067 \\
\hline Meliaceae & Entandrophragma cylindricum & 2 & 0.00494 \\
\hline Meliaceae & Guarea thompsonii & 2 & 0.00741 \\
\hline Meliaceae & Khaya ivorensis & 1 & 0.00247 \\
\hline Meliaceae & Lovoa trichilioides & 1 & 0.00247 \\
\hline Mimosoideae & Albizia ferruginea & 3 & 0.00989 \\
\hline Mimosoideae & Albizia gumifera & 2 & 0.00741 \\
\hline Mimosoideae & Albizia zygia & 3 & 0.01112 \\
\hline Mimosoideae & Cylicodiscus gabunensis & 1 & 0.00124 \\
\hline Mimosoideae & Parkia bicolor & 2 & 0.00618 \\
\hline Mimosoideae & Piptadeniastrum africanum & 3 & 0.00989 \\
\hline Mimosoideae & Tetrapleura tetraptera & 1 & 0.00371 \\
\hline Moraceae & Antiaris welwitschii & 2 & 0.00494 \\
\hline Moraceae & Ficus lutea & 2 & 0.00741 \\
\hline Moraceae & Ficus mucuso & 3 & 0.00989 \\
\hline Moraceae & Milicia excelsa & 1 & 0.02348 \\
\hline Moraceae & Treculia africana & 2 & 0.01236 \\
\hline Moraceae & Treculia obovoidea & 0.01359 \\
\hline Myristicaceae & Coelocaryon preussii & 0.00618 \\
\hline Myristicaceae & Pycnathus angolensis & 0.00124 \\
\hline Myristicaceae & Staudtia stipitata & Lophira alata & 0.00247 \\
\hline Ochnaceae & Strombosia pustulata & \\
\hline Olacaceae & & 204202 \\
\hline
\end{tabular}




\begin{tabular}{|l|l|l|l|}
\hline Papilionoideae & Amphimas pterocarpoides & 3 & 0.00865 \\
\hline Papilionoideae & Baphia nitida & 2 & 0.00494 \\
\hline Papilionoideae & Pentaclethra mycophylla & 1 & 0.00124 \\
\hline Papilionoideae & Pterocarpus osun & 5 & 0.01607 \\
\hline Papilionoideae & Pterocarpus soyauxii & 1 & 0.00124 \\
\hline Rhizophoraceae & Anopyxis klaineana & 1 & 0.00247 \\
\hline Rubiaceae & Mitragyna stipulosa & 2 & 0.00741 \\
\hline Rubiaceae & Nauclea diderrichii & 1 & 0.00124 \\
\hline Rubiaceae & Pausinystalia macrocera & 2 & 0.00494 \\
\hline Simaroubaceae & Hannoa klaineana & 2 & 0.00741 \\
\hline Sterculiaceae & Cola spp & 1 & 0.00371 \\
\hline Sterculiaceae & Sterculia oblonga & 12 & 0.04078 \\
\hline Sterculiaceae & Triplochiton scleroxylon & 4 & 0.01483 \\
\hline Ulmaceae & Celtis zenkeri & 13 & 0.04572 \\
\hline Verbenaceae & Vitex gradifolia & 8 & 0.02719 \\
\hline
\end{tabular}

Table 3. Pattern of Families Distribution by Genera and Species

\begin{tabular}{|c|c|c|c|}
\hline Families & Number of genera & Number of species & Average trees/Hectare \\
\hline Anacardiaceae & 1 & 1 & 6 \\
\hline Anisophylleaceae & 1 & 1 & 7 \\
\hline Annonaceae & 2 & 3 & 4 \\
\hline Apocynaceae & 3 & 3 & 12 \\
\hline Bombacaceae & 2 & 2 & 5 \\
\hline Burseraceae & 1 & 1 & 5 \\
\hline Caesalpinioideae & 10 & 10 & 37 \\
\hline Combretaceae & 1 & 2 & 14 \\
\hline Ebenaceae & 1 & 1 & 15 \\
\hline Ericaceae & 1 & 1 & 1 \\
\hline Euphorbiaceae & 3 & 3 & 24 \\
\hline Flacourtiaceae & 1 & 1 & 7 \\
\hline Guttiferae & 2 & 2 & 4 \\
\hline Irvingiaceae & 1 & 1 & 7 \\
\hline Lauraceae & 1 & 1 & 1 \\
\hline Lecythidaceae & 1 & 1 & 1 \\
\hline Loganiaceae & 1 & 1 & 2 \\
\hline Meliaceae & 5 & 5 & 21 \\
\hline Mimosoideae & 5 & 7 & 15 \\
\hline Moraceae & 3 & 6 & 14 \\
\hline Myristicaceae & 3 & 3 & 35 \\
\hline Ochnaceae & 1 & 1 & 7 \\
\hline Olacaceae & 1 & 1 & 4 \\
\hline Papilionoideae & 4 & 5 & 12 \\
\hline
\end{tabular}




\begin{tabular}{|c|c|c|c|}
\hline Rhizophoraceae & 1 & 1 & 1 \\
\hline Rubiaceae & 3 & 3 & 5 \\
\hline Simaroubaceae & 1 & 1 & 2 \\
\hline Sterculiaceae & 3 & 3 & 17 \\
\hline Ulmaceae & 1 & 1 & 13 \\
\hline Verbenaceae & 1 & 1 & 8 \\
\hline
\end{tabular}

\subsection{Diversity Index}

Table 4 shows summary of diversity indices for Oban Forest Reserve. The species richness index obtained was 10.605, which indicate high species richness. The Shannon index measures the relative abundance of species. The value of Shannon-Wiener Index $\left(\mathrm{H}^{\mathrm{I}}\right)$ is 3.795 which is quite high compared to 2.20-2.65 for the tropical forests of Kodayar in the Western Ghats of southern India (Sundaranpandian et al, 2000). The Shannon-Wiener Index $\left(\mathrm{H}^{\mathrm{I}}\right)$ can as well be compare to tree species diversity values in tropical forests of Kalakad Reserved Forests in Western Ghats which were reported as 3.31 and 3.69 (Parthasarathy et al, 1992), and in tropical forests of Barro Colorado Island in Panama as 4.8 (Knight, 1975). However, quantitative comparisons of species diversities in this study area with other studies elsewhere depend on sample size, plot size, environmental conditions, and other site factors.

The Simpson's Index $\left(\mathrm{D}^{\mathrm{I}}\right)$ (reciprocal form) obtained was 33.490 (Table 4), which mean Oban Forest Reserve has a high diversity value. This is in agreement with Young and Swiacki (2006) who stated that diversity was made up of the variety of species present and the relative abundance of those species. The higher the values, the higher the diversity (Ojo 2004). The Simpson's Index (D) of 0.029 (Table 4) indicates that the diversity of the reserve is high and it is an indicative of a healthy reserve.

Table 4. Summary of the Various Diversity Calculated for Oban Forest Reserve

\begin{tabular}{|l|c|}
\hline Characteristic & Oban Forest Reserve \\
\hline Species Richness $(\mathrm{d})$ & 10.605 \\
\hline Shannon-Wiener $\left(\mathrm{H}^{\mathrm{I}}\right)$ & 3.795 \\
\hline Evenness Index $(\mathrm{E})$ & 0.887 \\
\hline Simpson's Index $(\mathrm{D})$ & 0.030 \\
\hline Simpson's Index $\left(\mathrm{D}^{\mathrm{I}}\right)$ & 33.490 \\
\hline
\end{tabular}

\section{Conclusion}

Oban Forest Reserve is not only important in terms of plant biodiversity but also they are considered as important destination point for rich timber resources. In this forest, economically and ecologically very important tree species such as Diospyros crassiflora, Petersianthus macrocarpus, Entandrophragma cylindricum, Khaya ivorensis, Piptadeniastrum africanum, Milicia excelsa, Lophira alata, Strombosia pustulata etc are found. Hence, it is very crucial to protect these important forests from biodiversity, sustainable management and environmental perspectives.

The presence of Thaumatococcus danielli, Musanga cecropioides and Aframomum latifolium in the study area, is an indication that the vegetation has been disturbed in the recent past, but 
currently displays signs of recovery. Evidently, the forest reserve is very rich in trees in the lower diameter classes, which is an indication of a healthy and vigorous stand. The high species diversity and the relative richness in timber species of the forest reserve does not correlate well with the abundance because the abundance of each of the species was quite low and density poor. Some tree species encountered translates to one stand per hectare. To prevent the extinction of some families particularly the monospecific ones, urgent steps therefore need to be taken to arrest the dwindling density of timber and the forest reserve should be restocked, especially the species having only one stand. Exploitation of timber resources need to be drastically reduced to allow the forest to regenerate itself.

\section{Acknowledgement}

The research is partly financed by Tertiary Education Trust Fund, Nigeria. I wish to thank Professors S. O. Akindele and J. C. Onyekwelu for their contribution and constructive critisicm.

\section{Reference}

Adekunle, V. A. J. Akindele, S. O., \& Fuwape, J. A. (2004). Structure and yield models of tropical lowland rainforest ecosystem of southwest Nigeria, Food, Agriculture and Environment, 2(2), 395-399.

Adekunle, V. A. J., \& Olagoke, A. O. (2008). Diversity and bio-volume of tree species in natural forest ecosystem in the bitumen-producing area of Ondo State, Nigeria: A baseline study, Biodiversity and Conservation, 17, 2735-2755. http://dx.doi.org/10.1007/s10531-007-9279-y

Akinsanmi, F. A. (1999). Updating Environmental Information in Nigeria. Invited Lead paper presented at the $26^{\text {th }}$ Annual Conference of the Forestry Association of Nigeria held in Maiduguri, Borno. November 7-12, 1999. 15p.

Alder, D., \& Abayomi, J. O. (1994). Assessment of data requirements for sustained yield calculations, Unpublished report prepared for the Nigeria Tropical Action Programme, FORMECU, Federal Department of Forestry, Ibadan, Nigeria, p. 28.

Bobo, K. S., Waltert, M., Sainge, M., Njokagbor J., Fermon, H., \& Mühlenberg, M. (2006). From forest to farmland: Species richness patterns of trees and understorey plants along a gradient of forest conversion in Southwestern Cameroon, Biodiversity and Conservation, 15, 4097-4117. http://dx.doi.org/10.1007/s10531-005-3368-6

Boubli J. P., Eriksson J., Wich S., Hohmann G., \& Fruth B. (2004).Mesoscaletransect sampling of trees in the Lomako-Yekokorainterfluvium, Democratic Republic of the Congo, Biodiversity and Conservation, 13, 2399-2417. http://dx.doi.org/10.1023/B:BIOC.0000048445.27943.81

Campbell, D. G., Daly, D. C., Prance, G. T., \& Maciel U. N. (1986).Quantitative ecological inventory of Terra firma and the Varzeatropical forest on the Rio Xingu, Brazilian Amazon. Brittanica, 38, 369-393. http://dx.doi.org/10.2307/2807085

Campbell, D. G., Stone, J. L., \& Rosas A. Jr. (1992). A comparison of phytosociology and 
dynamics of three flood plains (Varzea) forests of known age, Rio Jurua, Western Brazilian $\begin{array}{lllll}\text { Amazon. Bot. } \quad \text { J. Linn. } & \text { Soc.108, }\end{array}$ http://dx.doi.org/10.1111/j.1095-8339.1992.tb00240.x

Christie, D. A., \& Armesto .J. (2003). Regeneration at micro site and tree species co-existence in temperate rainforest of Chilue Island, Chile. J. Ecol., 91, 776-84. http://dx.doi.org/10.1046/j.1365-2745.2003.00813.x

FAO, (2011): State of the World's Forests, 2011, FAO Rome, 164 pp.

FRA, (2010): Global Forest Resources Assessment 2010, Main report. FAO Forestry Paper, 163, FAO Rome, 340 pp.

Gebreselasse, G. V. (2011). Plant communities species diversity seedling bank and re-sprouting in Nandi Forest, Kenya. PhD Thesis, Universitat Koblenz-Landau.

Gillespie, T. W., Brock J., \& Wright C. W. (2004). Prospects for quantifying structure, floristic composition and species richness of tropical forest. Int. J. Remote Sens., 25, 70-7. http://dx.doi.org/10.1080/01431160310001598917

Hadi.S., Ziegler T.,Waltert M., \& Hodges J. K. (2009).Tree diversity and forest structure in northern Siberut, Mentawai islands, Indonesia, Tropical Ecology, 50(2), 315-327.

Hartshorn, G. S. (1980). Neotropical forest dynamics, Biotropica, 12, 23-30. http://dx.doi.org/10.2307/2388152

Ho, C. C., Newbery, D. M. C., \& Poore, M. E. D. (1987). Forest composition and inferred dynamics in Jengka forest reserve, Malaysia. J. Trop. Ecol. 3, 25-26. http://dx.doi.org/10.1017/S0266467400001103

Holland, M. D., Allen, R. K. G., Barton, D., \& Murphy, S. T. (1989). Cross River National Park (Oban Division); Land Evaluation and Agricultural Recommendations. World Wide Fund for Nature, Godalming, United Kingdom.140pp.

ITTO (2011). Status of tropical forest management.Technical series 38. 420pp.

IUCN (2010). Plants under pressure - a global assessment. The first report of the IUCN Sampled Red List Index for Plants. Royal Botanic Gardens, Kew, UK, Natural History Museum, London, and International Union for Conservation of Nature.

Jimoh S. O., Adesoye P. O., Adeyemi A. A., \& Ikyaagba E. T., (2012). Forest Structure Analysis in the Oban Division of Cross River National Park, Nigeria. Journal of Agricultural Science and Technology B 2, 510-518.

Knight, D. H., (1975).A phytosociological analysis of species rich tropical forest on Borro Colorado Island, Panama. Ecol. Monogr., 45, 259-284. http://dx.doi.org/10.2307/1942424

Kumar, A., Gupta, A. K., Marcot, B. G., Saxena, A., Singh, S. P., \& Marak, T. T. C. (2002). Management of forests in India for biological diversity and forest productivity, a new perspective. Volume IV: Garo Hills Conservation Area (GCA). Wildlife Institute of India 
-USDA Forest Service collaborative project report, Wildlife Institute of India, Dehra Dun, p. 206.

Ojo L. O. (2004): The fate of a tropical rainforest in Nigeria: Abeku sector of Omo Forest Reserve. Global Nest: The International Journal, 6(2), 116-130.

Olajide, O. (2004). Growth performance of trees in Akure Forest Reserve, Ondo State, Nigeria. Un-published Ph.D. Thesis, University of Ibadan, Ibadan, Nigeria.

Onyekwelu, J. C., Mosandl, R., \& Stimm, B. (2008).Tree species diversity and soil status of primary and degraded tropical rainforest ecosystems in South-Western Nigeria. Journal of Tropical Forest Science, 20(3), 193 -204.

Parthasarathy, N., Studies on the vascular (1986). Flora, Structure and Nutrient Cycling in Kalakad Reserve Forest, Western Ghats, TamilNadu. Ph D thesis, University of Madras.

Sarumi, M. B., Ladipo, D. O., Denton, L., Olapade, E. O., Badaru, K., Ughasoro, C. (1996). Nigeria Country report to FAO. International Technical Conference on plant Genetic Resources. Leipzig, Germany. 17-23 June, 108.

Schmitt K. (1996). Zoological survey of the Oban division of Cross River National Park. Oban Hill programme, Calabar. Pp 21.

Schmitt, C. B., Burgess, N. D., Coad, L., Belokurov, A., Besançon, C., Boisrobert, L., Campbell, A., Fish, L., Gliddon, D., Humphries, K., Kapos, V., Loucks, C., Lysenko, I., Miles, L., Mills, C., Minnemeyer, S., Pistorius, T., Ravilious, C., Steininger, M., \& Winkel, G. (2009). Global analysis of the protection status of the world's forests. Biological Conservation, 142(10), 2122-2130. http://dx.doi.org/10.1016/j.biocon.2009.04.012

Sidiyasa, K. (2001). Tree Diversity in the Rain Forest of Kalimantan, The Tropenbos Foundation, Wageningen, The Netherlands.

Sundarapandian, S. M., \& Swamy, P. S. (2000). Forest ecosystem structure and composition along an altitudinal gradient in the WesternGhats, South India. J. Trop. For. Sci., 12, 104-123.

Thorington, R. W., Tannenbaum, S., Tarak, A., \& Rudran, R. (1982). Distribution of trees in Barocolorado Islands: A five hectare sample. In The Ecology of a Tropical Forest - Seasonal Rhythms and Long-term Changes (eds Leigh Jr., E. G. Rand, A. S. and Windsor,D. M.), Smithsonian Institute Press, Washington DC.

Turner, I. M. (2001). The Ecology of Trees in the Tropical Rainforest.Cambridge University Press. Cambridge p. 298. http://dx.doi.org/10.1017/CBO9780511542206

Young S. and Swiacki L. N. (2006). Surveying the Forest Biodiversity of Evansburg State Park: Plant Community Classification and Species Diversity Assessment. International Journal of Botany, 2(3), 293-299. http://dx.doi.org/10.3923/ijb.2006.293.299

\section{Copyright Disclaimer}

Copyright for this article is retained by the author(s), with first publication rights granted to 
the journal.

This is an open-access article distributed under the terms and conditions of the Creative Commons Attribution license (http://creativecommons.org/licenses/by/3.0/). 